\title{
Survey of Wheelchair Athletic Injuries: Common Patterns and Prevention
}

\author{
Kathleen A. Curtis, M.A., R.P.T. ${ }^{1}$ and Deborah A. Dillon, M.P.H. ${ }^{2}$ \\ ${ }^{1}$ Programs in Physical Therapy, Mount St Mary's College, Los Angeles, California, \\ U.S.A. ${ }^{2}$ Northern California Regional Spinal Injury System, Institute for Medical \\ Research, 2260 Clove Drive, San fose, California 95128, U.S.A.
}

\section{Summary}

Twelve hundred wheelchair athletes were surveyed to determine commonly experienced athletic injuries, sports participation and training patterns associated with injuries. Soft tissue trauma, blisters, lacerations, decubiti and joint disorders were the most commonly reported injuries of the 128 respondents. Over 70 per cent of all reported injuries occurred during wheelchair track, road racing and basketball. Common mechanisms of injury were also identified. A significantly higher number of reported injuries were associated with increased sports participation $(p<001)$, with the 21-30 year-old age group $(p<\cdot 01)$, and with a high number of training hours per week $(p<\cdot 05)$. There was no significant relationship between number of reported injuries and disability type, National Wheelchair Athletic Association classifcation, or sex. Decubitus ulcers and temperature regulation disorders were identified as particular risks for the spinal cord injury population. Educating the athlete and coach in means to prevent injury is necessary to promote optimal performance and safe participation. Key words: Wheelchair athletics; Injuries; Prevention; Sportsmedicine.

\section{Introduction}

An estimated 4000-5000 physically disabled individuals are involved in organised athletic competition within the United States. A large number also participate in recreational sports. The scope of wheelchair athletic participation includes swimming, track and field, road racing, archery, weight lifting, table tennis, tennis, basketball, winter sports, bowling, billiards, boating and many other recreational and competitive sports.

Although numerous publications in recent years have addressed injury prevention and treatment for the able-bodied athlete, little information is available on injuries sustained by the wheelchair athlete. Jackson (1979) reported that 184 athletes were treated for a variety of injuries at the 1976 Torontolympiad for 
the Physically Disabled. Corcoran (1980) discussed the potential risks of wheelchair marathon racing. In addition, chronic shoulder problems have been identified as a complication of long-term wheelchair use, especially with increasing age (Nichols, 1979).

The purpose of this study is to determine commonly experienced athletic injuries, sports participation and training patterns associated with injuries among wheelchair athletes. The prevention of such injuries is discussed in this paper.

\section{Method}

A questionnaire was distributed to over 1200 disabled athletes. Information was collected regarding each individual's disability, wheelchair sports participation, use of protective gear and history of injuries sustained during these sports activities. There were 128 questionnaires completed.

\section{Results}

One hundred and one (101) men (79\%) and 27 women $(21 \%)$ responded. Mean age of respondents was $29 \cdot 25 \pm 7.59$ years with a range of 14 to 53 , and athletes averaged $14.13 \pm 10.39$ years since onset of disability. Disabilities included 65 per cent spinal cord injury, 13 per cent post-poliomyelitis, 9 per cent congenital disorders, 3 per cent amputations and 10 per cent other neuromuscular and musculo-skeletal disorders. A breakdown by neurological level using National Wheelchair Athletic Association (NWAA) Classification shows that Class IV (T10 to L2 paraplegia) was the largest group for both men and women, comprising 28 per cent of the total group.

\section{Wheelchair sports participation history}

Thirty-two different sports were listed by the athletes responding to the questionnaire. The largest percentages of athletes were involved in track $(79 \%)$, basketball $(71 \%)$, swimming $(61 \%)$, field events $(60 \%)$ and road racing $(57 \%)$.

Both males and females reported an average sports participation of $4.35 \pm 1.76$ days per week. Athletes reported training from zero to over 25 hours per week, with the most common time being from 6-10 hours $(36 \%)$. Sixty-nine per cent of all who responded reported using protective gear such as gloves, safety glasses or helmets during sports participation to minimise the risks of injury.

\section{Sports injuries}

Seventy-two per cent of all athletes responding reported at least one injury from the time of initial participation in wheelchair sports, with some reporting as many as 14 injuries. The 93 athletes who reported injuries sustained a total of 291 injuries. Common injuries reported are listed in Table 1. The most prevalent were soft tissue injuries $(33 \%)$, blisters $(18 \%)$ and skin lacerations/abrasions $(17 \%)$.

Soft tissue injuries, including muscle-pulls, strains, sprains, bursitis and tendonitis, were frequently reported at shoulders, elbows, wrists and hands. 
Table 1 Common Wheelchair Sports Injuries

\begin{tabular}{|c|c|c|c|}
\hline \multicolumn{2}{|l|}{ Injury } & \multicolumn{2}{|c|}{$\begin{array}{c}\text { Percentage of all } \\
\text { Injuries Reported }(\mathrm{N}=291)\end{array}$} \\
\hline \multicolumn{2}{|c|}{ Soft Tissue Injuries ${ }^{\star}$} & \multicolumn{2}{|c|}{33} \\
\hline \multicolumn{2}{|c|}{ Blisters } & \multicolumn{2}{|c|}{18} \\
\hline \multicolumn{2}{|c|}{ Lacerations/Abrasions/Cuts $\dagger$} & \multicolumn{2}{|c|}{17} \\
\hline \multicolumn{2}{|c|}{ Decubitus/Pressure Areas } & \multicolumn{2}{|c|}{7} \\
\hline \multicolumn{2}{|c|}{ Arthritis/Joint Disorders } & \multicolumn{2}{|r|}{5} \\
\hline \multicolumn{2}{|c|}{ Fractures } & \multicolumn{2}{|r|}{5} \\
\hline \multicolumn{2}{|c|}{ Hand Weakness/Numbness } & \\
\hline \multicolumn{3}{|c|}{ Temperature Regulation Disorders } & $\begin{array}{l}5 \\
3\end{array}$ \\
\hline \multicolumn{2}{|c|}{ Head Injury/Concussion } & \multicolumn{2}{|r|}{2} \\
\hline \multicolumn{2}{|c|}{ Dental Injury } & \multicolumn{2}{|r|}{1} \\
\hline \multicolumn{4}{|c|}{$\begin{array}{l}\text { ^Soft Tissue includes sprains, strains, muscle pulls, tendonitis, } \\
\text { bursitis. } \\
\text { †Lacerations includes skin infections and other subsequent } \\
\text { complications. }\end{array}$} \\
\hline ort & $\begin{array}{l}\text { Number of } \\
\text { injuries } \\
\text { reported }\end{array}$ & $\begin{array}{l}\text { Percent of total } \\
\text { injuries reported } \\
\quad(\mathrm{N}=291)\end{array}$ & $\begin{array}{l}\text { Percent of athletes } \\
\text { participating } \\
(\mathrm{N}=128)\end{array}$ \\
\hline race & 93 & 26 & 79 \\
\hline sketball & 84 & 24 & 71 \\
\hline oadracing & 77 & 22 & 57 \\
\hline ennis & 20 & 6 & 33 \\
\hline eld events & 15 & 4 & 60 \\
\hline
\end{tabular}

Many of these injuries were recurrent. Few athletes reported seeking medical attention or treatment and tended to use self-treatment for these injuries. Blisters of the hands and fingers and skin lacerations of the hands, fingers and arms also occurred commonly.

The majority of injuries were associated with track (26\%), basketball (24\%) and road racing $(22 \%)$ (See Table 2 ). Injury risk level has been calculated for all sports in which at least 30 athletes indicated that they participated (Fig. 1). The three highest risk sports for injury in this sample were road racing, basketball and track. Very low injury risk sports include pool, bowling, archery, slalom and table tennis.

For the five highest risk sports individual sport injury patterns varied somewhat. Soft tissue injuries accounted for 33-53 per cent of all injuries in each of the highest risk sports except track, where blisters accounted for 29 per cent of injuries, and soft tissue injuries followed with 27 per cent. Blisters of the hands were a significant problem (20-30 per cent of all reported injuries) in road racing, basketball, track and tennis and, not surprisingly, absent in the field event athlete.

Those athletes involved in a higher number of sports over their participation history report a significantly higher number of injuries $(\mathrm{p}<\cdot 0001)$.

Similarly, a higher number of hours per week spent training was related to a higher number of injuries reported $(\mathrm{p}<\cdot 02)$. A higher than expected proportion of injuries $(\mathrm{p}<\cdot 01)$ was found in the $21-30$ years age group. 


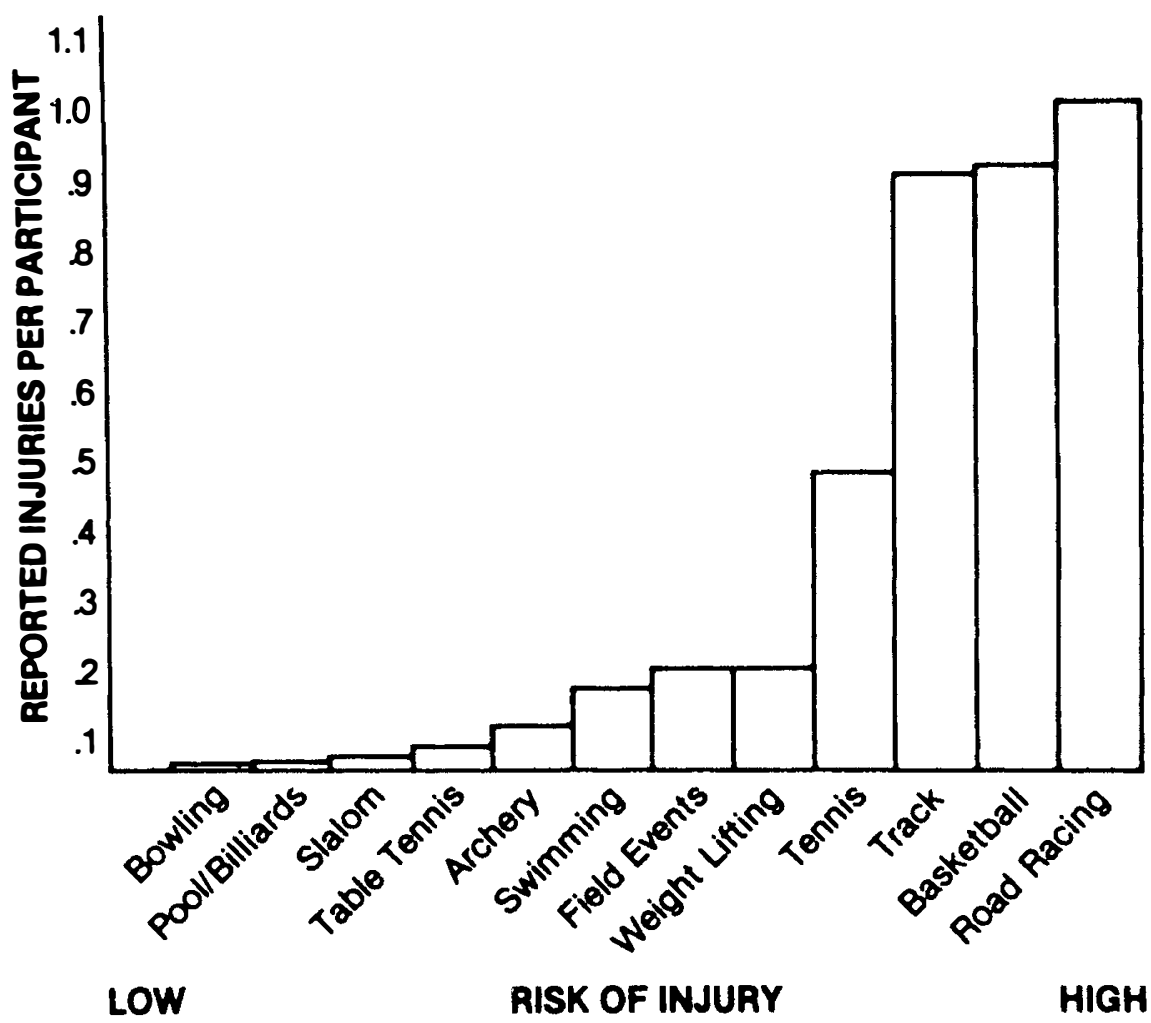

Figure 1. Relative occurrence of reported injuries by sport involvement. Road racing, basketball and track injuries account for 72 per cent of all reported injuries.

There was no significant relationship between sex or age training patterns nor any difference between males and females and number of injuries reported. Disability type and NWAA classification were also not significantly related to the number of injuries reported.

\section{Discussion}

A fairly consistent pattern among the high-risk repetitive wheelchair pushing sports (road racing, basketball, track and tennis) were soft tissue injuries, blisters, abrasions and lacerations of hands and arms, and hand weakness/numbness. These findings may indicate an over-use phenomenon, with injury resulting from continuous use of the arms to push the wheelchair. Of particular concern are the soft tissue injuries and hand weakness/numbness which may become chronic problems.

Ligamentous sprains, tendonitis and bursitis may result in chronic problems if treated improperly (O'Donaghue, 1976). Preventive measures should be taken to decrease risk of further injury. As performance can be altered drastically by a recurrent injury, it is in the athlete's best interest to rest an injury, seek medical 
Table 3 Injury Causes and Prevention in Wheelchair Athletics

\begin{tabular}{|c|c|}
\hline \multicolumn{2}{|c|}{ Soft Tissue Injuries } \\
\hline $\begin{array}{l}\text { Ligamentous injury (falls, physical contact) } \\
\text { Over-use muscles, tendons } \\
\text { Overexertion without warmup }\end{array}$ & $\begin{array}{l}\text { Routine stretching, warm-up, cool-down } \\
\text { Protection of old injuries (splinting, taping) } \\
\text { Slow progression of conditioning program } \\
\text { Rest, proper treatment of recurrent injuries }\end{array}$ \\
\hline $\begin{array}{l}\text { Friction (hands on wheelchair push rim } \\
\text { Friction (back) on upholstery and/or seat post }\end{array}$ & $\begin{array}{l}\text { Encourage callous formation } \\
\text { Tape fingers; wear gloves } \\
\text { Pad seat post; wear shirt }\end{array}$ \\
\hline \multicolumn{2}{|c|}{ Abrasions/Lacerations } \\
\hline $\begin{array}{l}\text { Finger contact with brake, arm-rest socket or } \\
\text { pushrim }\end{array}$ & Remove hazardous wheelchair parts \\
\hline Scraping inner arms on tires & Wear arm guards-upper arms \\
\hline $\begin{array}{l}\text { Trapping fingers between wheelchairs } \\
\text { (basketball) }\end{array}$ & Camber wheels \\
\hline \multicolumn{2}{|c|}{ Decubitus/Pressure Areas } \\
\hline Friction, pressure buttocks/sacrum & Adequate cushioning under buttocks \\
\hline Wheelchair design (knees elevated) & $\begin{array}{l}\text { Skin checks, weight shifting } \\
\text { Nutrition, hygiene }\end{array}$ \\
\hline Sweat, moisture & Absorbent clothing \\
\hline \multicolumn{2}{|c|}{ Temperature Regulation Disorders } \\
\hline Exposure to heat/cold & Insulating clothing \\
\hline Inadequate autonomic regulation (SCI) & $\begin{array}{l}\text { Assisted heat convection } \\
\text { Minimise exposure }\end{array}$ \\
\hline Fluid loss/inadequate intake & Replace fluids \\
\hline
\end{tabular}

attention, and slowly start on a programme of progressive effort, endurance and power training before returning to a full workout or competitive schedule.

Hand weakness and numbness, commonly associated with the carpal tunnel syndrome, may be caused by the constant trauma and compression of the heel of the hand for each arm stroke on the push-rim. Pain or tingling in the thumb and first two fingers should be signs for the athlete to seek proper diagnosis and treatment.

Mechanisms of common injuries and means of prevention are described in Table 3. The high number of soft tissue injuries, blisters and lacerations point to the need for intervention and proper education of wheelchair athletes and coaches.

As a pilot investigation this study provides subjective, historical information from athletes, not a diagnosis or injury registry by sports medicine professionals. The sample responding to the survey was biased as they were most likely individuals either concerned enough about their injuries to report them or, more likely, to respond because they had sustained injuries. The intent of the survey was to gather information about trends seen in athletic injuries of wheelchair athletes.

In summary it may be helpful for future research in this area to be conducted on the basis of information reported by health professionals to determine the incidence of injury by using a random sample, and to include criteria for ranking the severity of a particular injury (i.e., days missed from training). Athletes, coaches and trainers need to be aware of the causes of and means of prevention 
of common wheelchair sports injuries. Good coaching, attention to equipment maintenance, good officiating and good health supervision can all optimize performance and prevent injury.

\section{Résumé}

Les courses sur route, le basket et les coures sur piste montraient le plus haut pourcentage de blessures résultant de l'athlétique en voiture de malade. Athlètes, entraîneurs et moniteurs ont besoin d'être avisés des causes et des moyens de prévention des blessures communes qui résultent des sports en voiture de malade. Le bon entraînement, les soins apportés à l'entretien du matériel, le bon remplissement des fonctions de contrôle et la bonne supervision médicale peuvent tous optimiser les performances at empêcher les blessures.

\section{Zusammenfassung}

Strassenrennen, Korbballspiel und Bahnrennen zeigten die höchste Prozentzahl der Rollstuhlathletik-Verletzungen. Athleten, Sportleiter und Trainer brauchen, mit den Ursachen und Verhütungsmitteln von üblichen Rollstuhlsport-Verletzungen bekannt zu sein. Gutes Training, Sorgen für die Materialerhaltung, gute Ausübung der Kontrollfunktionen und gute Gesundheitsaufsicht können alle die Leistungen möglichst verbessern und die Verletzungen vermeiden.

\section{References}

CoRCORAN PJ 1980 Sports medicine and the physiology of wheelchair marathon racing. Orthopedic Clinics of North America 11:697-716.

JACKSON RW 1979 Sports for the physically disabled, the 1976 Olympiad (Toronto). American Journal of Sports Medicine 7:293-296.

Nichols PJ 1979 Wheelchair user's shoulder? Shoulder pain in patients with spinal cord lesions. Scandinavian Journal of Rehabilitation Medicine 11:29-32.

O'Donaghue DH 1976 Treatment of Injuries to Athletes, 3rd Edn. W. D. Saunders, Philadelphia. 